Sociolinguistics in Ireland 
This page intentionally left blank 


\section{Sociolinguistics in Ireland}

Edited by

Raymond Hickey

University of Duisberg and Essen, Germany 


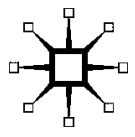

SOCIOLINGUISTICS IN IRELAND

Selection and editorial matter (c) Raymond Hickey 2016

Individual chapters (๑) Respective authors 2016

Softcover reprint of the hardcover 1st edition 2016 978-1-137-45346-4

All rights reserved. No reproduction, copy or transmission of this publication may be made without written permission. No portion of this publication may be reproduced, copied or transmitted save with written permission. In accordance with the provisions of the Copyright, Designs and Patents Act 1988, or under the terms of any licence permitting limited copying issued by the Copyright Licensing Agency, Saffron House, 6-10 Kirby Street, London EC1N 8TS.

Any person who does any unauthorized act in relation to this publication may be liable to criminal prosecution and civil claims for damages.

First published 2016 by PALGRAVE MACMILLAN

The authors have asserted their rights to be identified as the authors of this work in accordance with the Copyright, Designs and Patents Act 1988.

Palgrave Macmillan in the UK is an imprint of Macmillan Publishers Limited, registered in England, company number 785998, of Houndmills, Basingstoke, Hampshire, RG21 6XS.

Palgrave Macmillan in the US is a division of Nature America, Inc., One New York Plaza, Suite 4500, New York, NY 10004-1562.

Palgrave Macmillan is the global academic imprint of the above companies and has companies and representatives throughout the world.

ISBN 978-1-349-68697-1

E-PDF ISBN: 978-1-137-45347-1

DOI: $10.1057 / 9781137453471$

Distribution in the UK, Europe and the rest of the world is by Palgrave Macmillan ${ }^{\circledR}$, a division of Macmillan Publishers Limited, registered in England, company number 785998, of Houndmills, Basingstoke, Hampshire RG21 6XS.

A catalog record for this book is available from the Library of Congress.

A catalogue record for the book is available from the British Library. 


\section{Contents}

List of Figures vii

List of Tables viii

Preface and Acknowledgements $\quad \mathrm{x}$

Notes on the Contributors xii

The International Phonetic Alphabet xvii

Maps

Part I Language and Society in Contemporary Ireland

1 English in Ireland: Development and Varieties 3 Raymond Hickey

2 The Irish Language in Present-day Ireland 41 Brian Ó Catháin

3 The Irish Language and the Media 60 Iarfhlaith Watson

4 Irish-English Code-switching: a Sociolinguistic Perspective 81 Siobhán Ní Laoire

5 The Sociolinguistics of Language Use in Ireland 107 Anne Barron and Irina Pandarova

\section{Part II Language and Society in Irish History}

6 Language Relations in Early Ireland Patricia Ronan

7 From Early Modern Ireland to the Great Famine Liam Mac Mathúna

8 Language Shift and Language Revival in Ireland Regina Uí Chollatáin 
vi Contents

9 Language, Politics and Identity in Ireland: a Historical Overview

Tony Crowley

10 Emigrant Letters: Exploring the 'Grammar of the Conquered' Kevin McCafferty

11 Society, Language and Irish Emigration

Raymond Hickey

\section{Part III Sociolinguistic Interfaces}

12 Second-language Acquisition of Irish and the Role of Reading

Tina Hickey and Nancy Stenson

13 The Language of Irish Writing in English

Carolina P. Amador-Moreno

14 Irish Society as Portrayed in Irish Films

Shane Walshe

15 Translation and Society in Ireland, 1900-Present Kathleen Shields

16 Sociolinguistic Information and Irish English Corpora

Elaine Vaughan and Brian Clancy

Timelines

Glossary

General Bibliography

Index 


\section{List of Figures}

1.1 Short Front Vowel Lowering in recent Dublin English

1.2 The word dress for three speakers with increasingly lowered vowels from left to right (recognisable in the higher value for F1 towards the right)

1.3 Rotation in vowel space

6.1 Lexical fields of pre-thirteenth-century loanwords in Irish

10.1 BE-deletion in IrE: effect of following grammatical environment, 1731-1840 $(\mathrm{n}=253)$

10.2 BE-deletion in IrE: effect of subject type, 1731-1840 $(\mathrm{n}=253)$

10.3 First person shall/will in IrE letters, $1761-1890(n=1463)$

11.1 Major waves of emigration from Ireland to various destinations in the anglophone world

13.1 Quotative uses of go, be there and be like 307

13.2 Results of quotative forms in CIDN compared 308

13.3 Past and present tense uses compared 310

13.4 Distribution of quotatives across grammatical person 311

13.5 Reporting of male and female voices within third person subjects

16.1 Sample of concordance lines for shur in LCIE (sorted one item to the left) 


\section{List of Tables}

1.1 Shared features in vernacular varieties of (southern) Irish English

1.2 Suggestions for sources of key features of (southern)

Irish English (Hickey 2004a, 2007b)

1.3 Summary of the Dublin Vowel Shift from the 1990s

1.4 Changes in non-local Dublin English by speaker age

1.5 Levels of indexicality after Silverstein (2003)

5.1 Composition of the ICE-Ireland S1A sub-corpus comprised of speakers of NI/ROI background with TQ raw and relative frequencies per 10,000 words

5.2 The interactional functions of tag questions and their proportions in ICE-GB and ICE-Ireland private conversations (Barron et al. 2015)

5.3 The interactional functions of tag questions and their proportions in private conversations of NI and ROI speakers

5.4 The functions of TQs in women's and men's speech in ICE-Ireland according to regional background

10.1 BE-deletion in IrE: effect of following grammatical environment, 1731-1840 $(n=253)$

10.2 BE-deletion in IrE: effect of subject type, 1731-1840 $(\mathrm{n}=253)$

10.3 First person shall/will in IrE letters, $1761-1890(\mathrm{n}=1463)$

10.4 GoldVarb analysis of shall/will in late eighteenth-century IrE (1761-90)

10.5 GoldVarb analysis of shall/will in IrE (1831-40) 235

10.6 GoldVarb analysis of shall/will in IrE (1881-90) 235

11.1 Timeline for emigration from Ireland during the colonial period

11.2 Parallels between Glasgow English and Northern Irish English

13.1 Word list of 2-word clusters in CIDN

14.1 Grammatical features in Northern and Southern Irish films

14.2 Chronological list of Northern and Southern Irish films 
16.1 Linguistic and societal variables investigated in sociolinguistics

16.2 Existing Irish English corpora

16.3 Sure/shur(e) in LCIE, SPICE-Ireland and the BNC

16.4 Top ten keywords in LCIE using BNC Spoken as reference corpus

16.5 Sample of metadata preserved in the LCIE database 


\section{Preface and Acknowledgements}

The present volume gathers together a range of contributions by established scholars with the theme of language and society in Ireland, both in its history and the present day, as their central focus. There are many reasons why a book on sociolinguistics in Ireland is topical but the common thread throughout this volume is how the relationship of a society to the languages spoken by its members evolved, how it has been and is redefined afresh in successive generations. In today's Ireland this is true, as it was in the past, but perhaps now even more so, given the large number of people at present living in the country but born outside Ireland. This adds a further dimension to the interface of language and society which previously was solely determined by the relative positions of Irish and English to each other, the latter in many different varieties.

Contemporary Irish society has reacted to the languages it contains: linguistic issues are present in the media, and academic interest in these has burgeoned over the past few decades. In public the question of how modern Irish people view and engage with their heritage language, Irish, is a recurring topic. The attempts to adapt the Irish language to suit the world of the twenty-first century and the programmes to improve knowledge and use of the language in today's Ireland are matters which are keenly debated. These issues have a further political dimension, seeing as how the language question for both the Republic of Ireland and Northern Ireland has been addressed in the peace accord of the late 1990s, which continues to be implemented in both parts of the island of Ireland.

For readers new to the area of language and society in Ireland a comprehensive glossary of common terms in the field has been added and a set of general references has been provided, which might help those interested in Irish history, literature and culture to orient themselves in these areas.

For these reasons and many more, which will hopefully become apparent in the various chapters of the volume, this project was undertaken during the past few years. It would not have been completed without the dedication of all the contributors and, as an editor and author, I express my gratitude to all my colleagues whose work fills the 
pages of this book. My thanks also go to Libby Forrest and Rebecca Brennan at Palgrave Macmillan for their continual support for this project, and to the rest of the staff, especially the copy-editor Frances Tye, whose engaging work saw this volume swiftly and carefully to completion. 


\section{Notes on the Contributors}

Carolina P. Amador-Moreno is Senior Lecturer in English Linguistics, University of Extremadura, Spain. Her research interests centre on the English spoken in Ireland and include sociolinguistics, stylistics, discourse analysis, corpus linguistics and pragmatics. Publications include An Introduction to Irish English (2010), the co-edited volumes Writing Orality (2009) and Fictionalising Orality, and a special issue of the journal Sociolinguistic Studies (2011). Other publications include articles in the journals Intercultural Pragmatics, English Language and Linguistics, Irish University Review and the International Journal of English Studies. Current research projects include CONVAR (Contact, Variation and Change) in collaboration with Kevin McCafferty, at the University of Bergen.

Anne Barron is Professor of English Linguistics, Leuphana University, Lüneburg, Germany. Her main research interests lie in the areas of Irish English, variational pragmatics, interlanguage pragmatics and discourse analysis. Her publications include the monographs Acquisition in Interlanguage Pragmatics (2003) and Public Information Messages (2012) as well as the co-edited volumes The Pragmatics of Irish English (2005), Variational Pragmatics (2008) and Pragmatics of Discourse (2014). She is also series co-editor of 'Studies in Pragmatics' (Brill) and member of a number of editorial boards, including the Journal of Pragmatics, Intercultural Pragmatics and Study Abroad Research in Second Language Acquisition and International Education.

Brian Clancy lectures in academic writing and research methods at Mary Immaculate College, University of Limerick, Ireland. His research work focuses on the blend of a corpus linguistic methodology with the discourse analytic approaches of pragmatics and sociolinguistics. He is interested in the use of corpora in the study of language varieties, and the construction and analysis of small corpora. His published work addresses these areas and also explores corpus-based discourse analysis in intimate settings, such as between family and close friends, as well as varieties of Irish English. He is author of Investigating Intimate Discourse: Exploring the Spoken Interaction of Families, Couples and Close Friends (forthcoming) and co-author, with Anne O'Keeffe and Svenja Adolphs, of Introducing Pragmatics in Use (2011). 
Tony Crowley is Professor of English, University of Leeds, and a former visiting professor at the Institute of Irish Studies in Liverpool. He has published widely in the area of language and cultural theory, including Wars of Words: the Politics of Language in Ireland 1537-2004 (2005) and Scouse: a Social and Cultural History (2012). He also curates the Murals of Northern Ireland Collection at the Claremont Colleges Digital Library.

Raymond Hickey is Professor of English Linguistics, University of Duisburg and Essen, Germany. His main research interests are varieties of English (especially Irish English and Dublin English) and general questions of language contact, variation and change. Recent publications include Motives for Language Change (2003), A Sound Atlas of Irish English (2004), Legacies of Colonial English (2004), Dublin English. Evolution and Change (2005), Irish English: History and Present-day Forms (2007), The Handbook of Language Contact (2010), Eighteenth-Century English (2010), Varieties of English in Writing (2010), The Sound Structure of Modern Irish (2014) and A Dictionary of Varieties of English (2014).

Tina Hickey is a lecturer in the School of Psychology, University College Dublin. Her main research interests include first- and second-language acquisition, bilingualism and immersion education, family language transmission and minority language maintenance. Her publications include some of the earliest articles in international journals on the acquisition of Irish as L1, books on the development of L1-Irish-speaking children and L2 learners in immersion preschools (naíonraí), and articles on L2 reading in Irish. Her current work includes collaboration with Prof. Nancy Stenson within a Marie Curie International Fellowship on Irish orthography and the teaching of Irish reading.

Liam Mac Mathúna is Emeritus Professor of Irish, University College Dublin, where he was Head of the School of Irish, Celtic Studies, Irish Folklore and Linguistics, 2006-13. He also taught at Uppsala University and St Patrick's College, Drumcondra, Dublin, where he was Registrar, 1995-2006. His extensive publications on Irish language, literature and culture include Béarla sa Ghaeilge [English in Irish] (2007) a study of Irish/English code-mixing in literature composed in Irish 1600-1900, and a new edition of An tAthair Peadar Ua Laoghaire's novel, Séadna (2011). He is editor of Éigse: a Journal of Irish Studies, published by the National University of Ireland and is currently engaged in a study of the Ó Neachtain circle of Irish language scholars in Dublin, 1700-50, 
and the diaries of Douglas Hyde, 1874-1912, as part of a wider project researching the impact of modernity on Irish-speaking communities.

Kevin McCafferty is Professor of English Linguistics, University of Bergen, Norway. His research interests are in the field of language variation and change, with a focus on Irish English. His main publication to date is Ethnicity and Language Change: English in (London)Derry, Northern Ireland (2001). He is co-editor of Pragmatic Markers in Irish English (2015, with Carolina P. Amador-Moreno and Elaine Vaughan). Articles have appeared in Language Variation and Change, English World-Wide, Diachronica, Language and Literature, English Language and Linguistics, English Today, English World-Wide and American Speech. His current research activity is focused on compiling the Corpus of Irish English Correspondence and using it to research the history of Irish English.

Siobhán Ní Laoire is Lecturer in Irish and Chair of MA in Applied Irish, Dublin Institute of Technology, where she is also currently Head of the Department of Languages. She previously held positions in the Dublin Institute for Advanced Studies (1991-2005), St Patrick's College, Dublin City University and University College Dublin. Most of her research work in recent years has focused on register and stylistic variation in contemporary Irish.

Brian Ó Catháin is a senior lecturer in the Department of Modern Irish, National University of Ireland Maynooth. He completed his PhD on the language and oral narrative of Inis Oírr, Co. Galway at University College Dublin and has published widely on aspects of the linguistics and sociolinguistics of Modern Irish. He is the editor, with Ruairí Ó hUiginn, of Béalra: Aistí ar Theangeolaíocht na Gaeilge [Speech: Essays on the linguistics of Irish] (2001) and of Sochtheangealaíocht na Gaeilge [The Sociolinguistics of Irish] (2009).

Irina Pandarova is a research and teaching assistant in English Linguistics, Leuphana University, Lüneburg. Her main research interests are in the areas of variational pragmatics, the semantics/pragmatics interface (with a special focus on pragmatic markers), discourse analysis and Irish English. She is currently writing a PhD thesis on the semantics and pragmatics of the pragmatic marker sure across British, American and Irish English and is involved in a research project on tag questions across varieties of English. 
Patricia Ronan is Lecturer and Research Fellow in English Linguistics, Department of English, University of Lausanne. She has previously worked at the Universities of Uppsala, Bonn, the Basque Country and Maynooth. Her research interests comprise both English Linguistics and Celtic - especially the medieval Irish language. Recent publications include the monograph 'Make Peace' and 'Take Victory'. Support Verb Constructions in Old English in Comparison with Old Irish (2012), as well as the edited volume L'Irlande et ses contacts/Ireland and its contacts (2014).

Kathleen Shields is Lecturer in French, National University of Ireland Maynooth. Her main research interests are bilingual lexicography, translation studies and language policy. Recent publications include, as editor, Translating Emotion: Studies in Transformation and Renewal Between Languages, as well as many articles on translation and literature, for example in CLCWeb, Romance Studies and French Cultural Studies. She is currently working on a book project about the English language in France, L'anglais en France, attitudes, réalités et représentations.

Nancy Stenson is Professor Emerita of Linguistics, University of Minnesota, USA, and Adjunct Professor, School of Psychology, UCD, where she recently completed a Fulbright Fellowship and a Marie Curie Incoming International Fellowship. Her research interests include structural aspects of language contact in Irish and the acquisition of Irish as a second language. Recent publications include Basic Irish and Intermediate Irish (2008), An Haicléara Mánas (2003), and articles with Tina Hickey on Irish L2 literacy in Language, Culture and Curriculum and the Journal of Celtic Language Learning. Current projects include completion (with Tina Hickey) of a manual of Irish orthography for teachers and learners.

Regina Uí Chollatáin is a Senior Lecturer and Director of the de Bhaldraithe Centre for Irish Language Scholarship, University College Dublin. Her main areas of research are Irish language revival and media. Her books include An Claidheamh Soluis agus Fáinne an Lae 1899-1932 (2004), Iriseoirí Pinn na Gaeilge [Print-media journalists of Irish] (2008), co-edited publications include P. H. Pearse: Life and After-life (2009, with Roisín Higgins), An Greann sa Ghaeilge [Humour in Irish] (2013, with Malachy O'Neill), Cnuasach Comhar 1982-2012 (2014, with Aisling Ní Dhonnchadha), and Films gaèlics a Catalunya/Scannáin Ghaelacha sa Chatalóin [Gaelic films in Catalonia] (2014, with Jerry White). 
Elaine Vaughan is Lecturer in Applied Linguistics and Course Director for the MA TESOL, University of Limerick, Ireland. She has two main areas of teaching and research: language pedagogy for ELT/foreign language teaching, and using corpus-based methodologies to investigate varieties of English. She has published on teacher talk in workplace meetings (her PhD thesis) and language teachers as a community of practice, the pragmatics of Irish English and examining Irish English, discourse-pragmatic markers in spoken language, the use of humour and laughter in meetings and corpus linguistics more generally.

Shane Walshe is Lecturer in English, University of Zurich, Switzerland, and previously taught at the University of Bamberg, Germany. His main research interests are Irish English, literary dialect, perceptual dialectology and linguistic stereotyping. Irish English as Represented in Film (2009) examines the way in which Irish English is portrayed in 50 films set in Southern Ireland. Ongoing research projects include examinations of the portrayal of Irish speech in American comics and other forms of popular culture.

Iarfhlaith Watson is Lecturer in Sociology, University College Dublin, and a former President of the Sociological Association of Ireland. He publishes in both Irish and English. His research is mainly in the area of the Irish language, including his book Broadcasting in Irish (2003), and many articles and book chapters on linguistic elitism, Irish language media, and the educational advantages of speaking Irish. He has been a member of the Board of the International Visual Sociology Association and Irish Representative on the International Social Survey Programme, and has published on topics such as anti-immigrant attitudes and banal nationalism. 


\section{The International Phonetic Alphabet}

THE INTERNATIONAL PHONETIC ALPHABET (revised to 2005)

\begin{tabular}{|c|c|c|c|c|c|c|c|c|c|c|c|}
\hline & Bilabial & Labiodental & Dental & Alveolar & Postalveolar & Retroflex & Palatal & Velar & Uvular & Pharyngeal & Glottal \\
\hline Plosive & $\mathrm{p} \mathrm{b}$ & & & $\mathrm{t} d$ & & t d & c $\mathrm{f}$ & $\mathrm{k} \quad \mathrm{g}$ & q G & & $?$ \\
\hline Nasal & $\mathrm{m}$ & $\mathrm{m}$ & & $\mathrm{n}$ & & $\eta$ & $\mathrm{n}$ & $\eta$ & $\mathrm{N}$ & & \\
\hline Trill & B & & & $r$ & & & & & $\mathrm{R}$ & & \\
\hline Tap or Flap & & $V$ & & r & & r & & & & & \\
\hline Fricative & $\phi \beta$ & $\mathrm{V}$ & $\theta \delta$ & S Z Z & 3 & $S$ & ç $\dot{j}$ & $\gamma$ & $\chi$ в & & $\mathrm{h}$ \\
\hline $\begin{array}{l}\text { Lateral } \\
\text { fricative }\end{array}$ & & & & 13 & & & & & & & \\
\hline Approximant & & v & & I & & $\mathrm{t}$ & $\mathrm{j}$ & U & & & \\
\hline $\begin{array}{l}\text { Lateral } \\
\text { approximant }\end{array}$ & & & & 1 & & & $\Lambda$ & $\mathrm{L}$ & & & \\
\hline
\end{tabular}

Where symbols appear in pairs, the one to the right represents a voiced consonant. Shaded areas denote articulations judged impossible.

CONSONANTS (NON-PULMONIC)

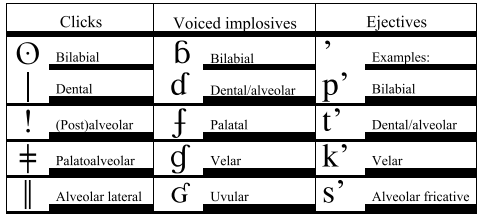

OTHER SYMBOLS

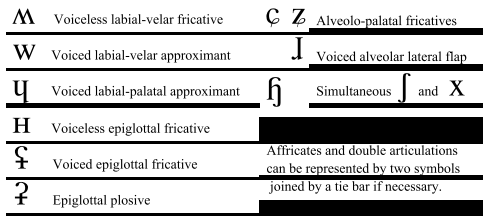

$\widehat{\mathrm{kp}}$ ts

DIACRITICS Diacritics may be placed above a symbol with a descender, e.g. $\stackrel{\circ}{\text { ] }}$

\begin{tabular}{|c|c|c|c|c|c|}
\hline . & Voiceless & $\mathrm{n}_{0} \mathrm{~d}$ & . & Breathy voiced $\quad \mathrm{b} \quad \underline{\mathrm{a}}$ & $\mathrm{t}_{n} \mathrm{~d}$ \\
\hline & Voiced & $\mathrm{S} t$ & $\sim$ & Creaky voiced $\underset{\sim}{\mathrm{b}} \underset{\sim}{\mathrm{a}}$ & $\mathrm{t} d$ \\
\hline $\mathrm{h}$ & Aspirated & $\mathrm{t}^{\mathrm{h}} \mathrm{d}^{\mathrm{h}}$ & 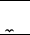 & $\begin{array}{lll}\text { Linguolabial } & \mathrm{t} & \mathrm{d}\end{array}$ & $\mathrm{t} d$ \\
\hline & More rounded & ว̧ & $\mathrm{W}$ & Labialized $\quad \mathrm{t}^{\mathrm{W}} \mathrm{d}^{\mathrm{w}}$ & $\sim$ Nasalized \\
\hline & Less rounded & כ) & $\mathrm{j}$ & Palatalized $\quad \mathrm{t}^{\mathrm{j}} \quad \mathrm{d}^{\mathrm{j}}$ & $\begin{array}{ll}\mathrm{n} & \\
& \text { Nasal release } \\
\end{array}$ \\
\hline & Advanced & $u_{+}^{u}$ & $\gamma$ & Velarized $\quad t^{\gamma} d^{\gamma}$ & $\begin{array}{ll}\text { Lateral release } \\
\end{array}$ \\
\hline- & Retracted & $\underline{e}$ & $\overline{\mathrm{S}}$ & Pharyngealized $t^{\hat{f}} \quad d^{\mathfrak{I}}$ & No audible release $\quad \mathrm{d}^{\urcorner}$ \\
\hline$\ddot{\ddot{\prime}}$ & Centralized & $\ddot{\mathrm{e}}$ & $\sim$ & Velarized or pharyngealized $t$ & \\
\hline $\bar{x}$ & Mid-centralized & ex & & Raised & $=$ voiced alveolar fricative) \\
\hline & Syllabic & $\mathrm{n}$ & $\tau$ & Lowered & $=$ voiced bilabial approximant) \\
\hline n & Non-syllabic & ę & -1 & Advanced Tongue Root & \\
\hline 2 & Rhoticity & $\partial^{2} a$ & & Retracted Tongue Root & \\
\hline
\end{tabular}

VOWELS

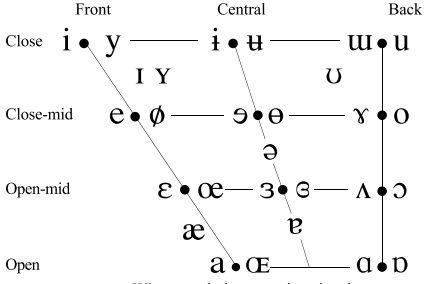

Where symbols appear in pairs, the one to the right represents a rounded vowel.

SUPRASEGMENTALS

I Primary stress

Secondary stress ,founa'tifon

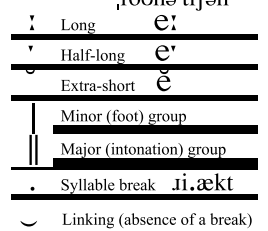

\begin{tabular}{|c|c|c|c|}
\hline \multicolumn{4}{|c|}{$\begin{array}{l}\text { TONES AND WORD ACCENTS } \\
\text { LEVEL } \\
\text { CONTOUR }\end{array}$} \\
\hline$\tilde{e}_{\text {or }}$ & $7 \begin{array}{l}\text { Extra } \\
\text { high }\end{array}$ & $\check{e}_{\text {or }} \Lambda$ & Rising \\
\hline é & $\dashv$ High & $\hat{\mathrm{e}}$ & Falling \\
\hline$\overline{\mathrm{e}}$ & $\dashv$ Mid & e & $\begin{array}{l}\text { High } \\
\text { rising }\end{array}$ \\
\hline è & $\dashv$ Low & è & $\begin{array}{l}\text { Low } \\
\text { rising }\end{array}$ \\
\hline è & \lrcorner $\begin{array}{l}\text { Extra } \\
\text { low }\end{array}$ & $\tilde{e}$ & $\begin{array}{l}\text { Rising- } \\
\text { falling }\end{array}$ \\
\hline$\downarrow$ & Downstep & & al rise \\
\hline$\uparrow$ & Upstep & $\searrow$ & al fall \\
\hline
\end{tabular}

https://www.internationalphoneticassociation.org/content/full-ipa-chart 
Maps

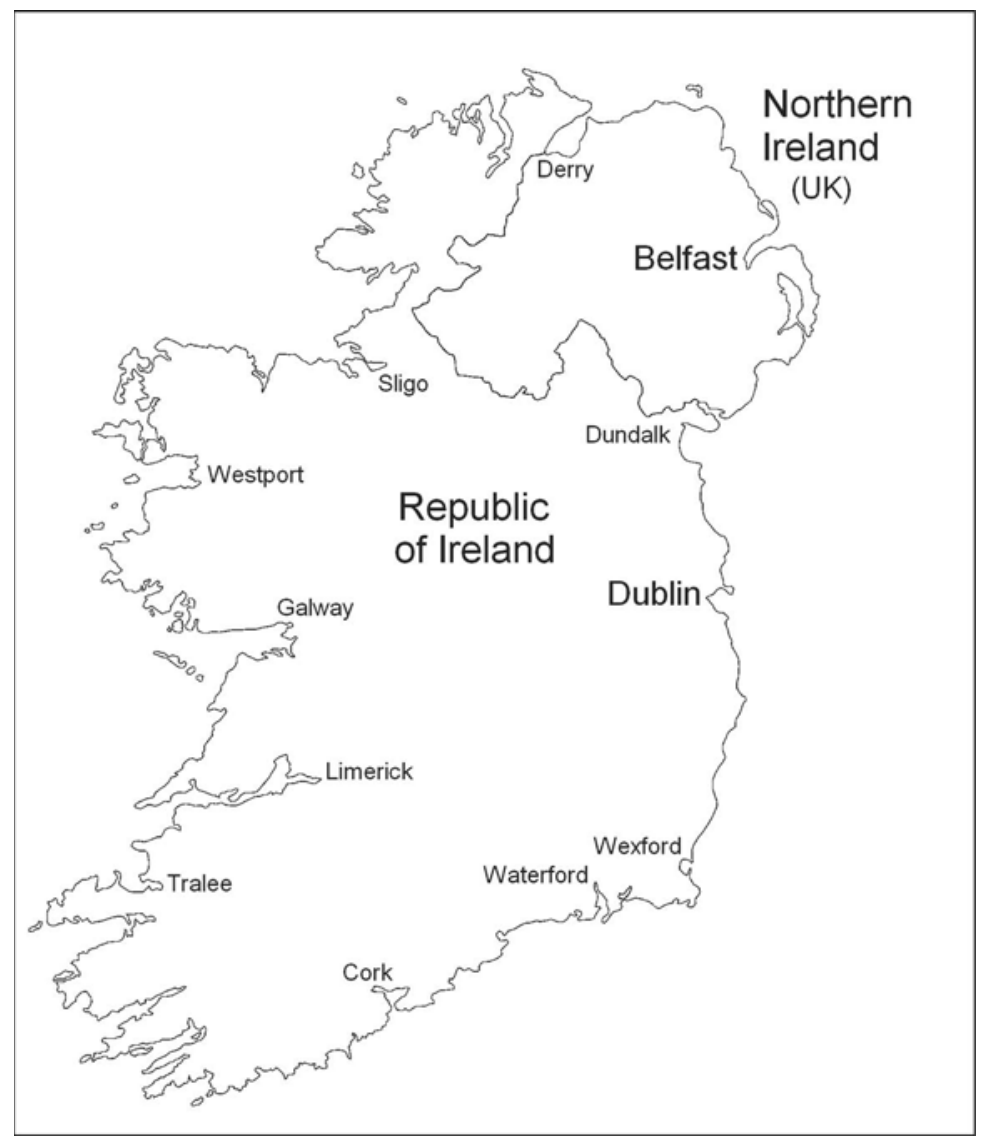

Map 1 Political division and cities in Ireland 


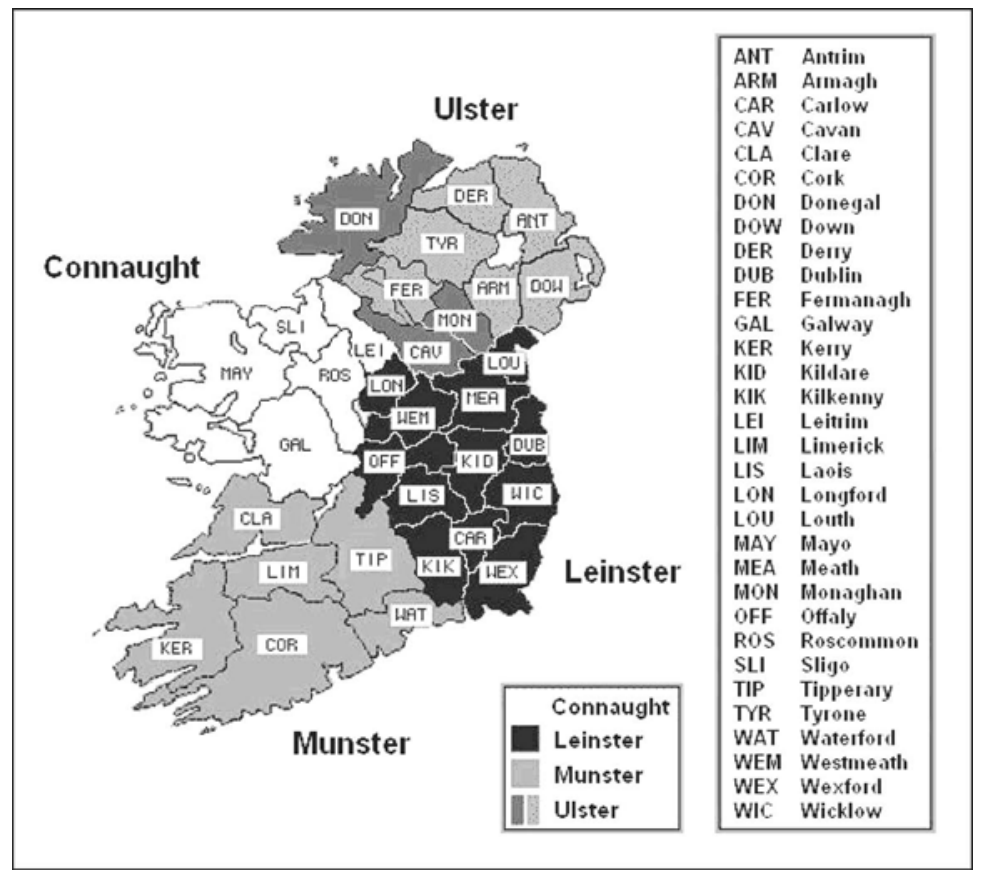

Map 2 Provinces and counties of Ireland 


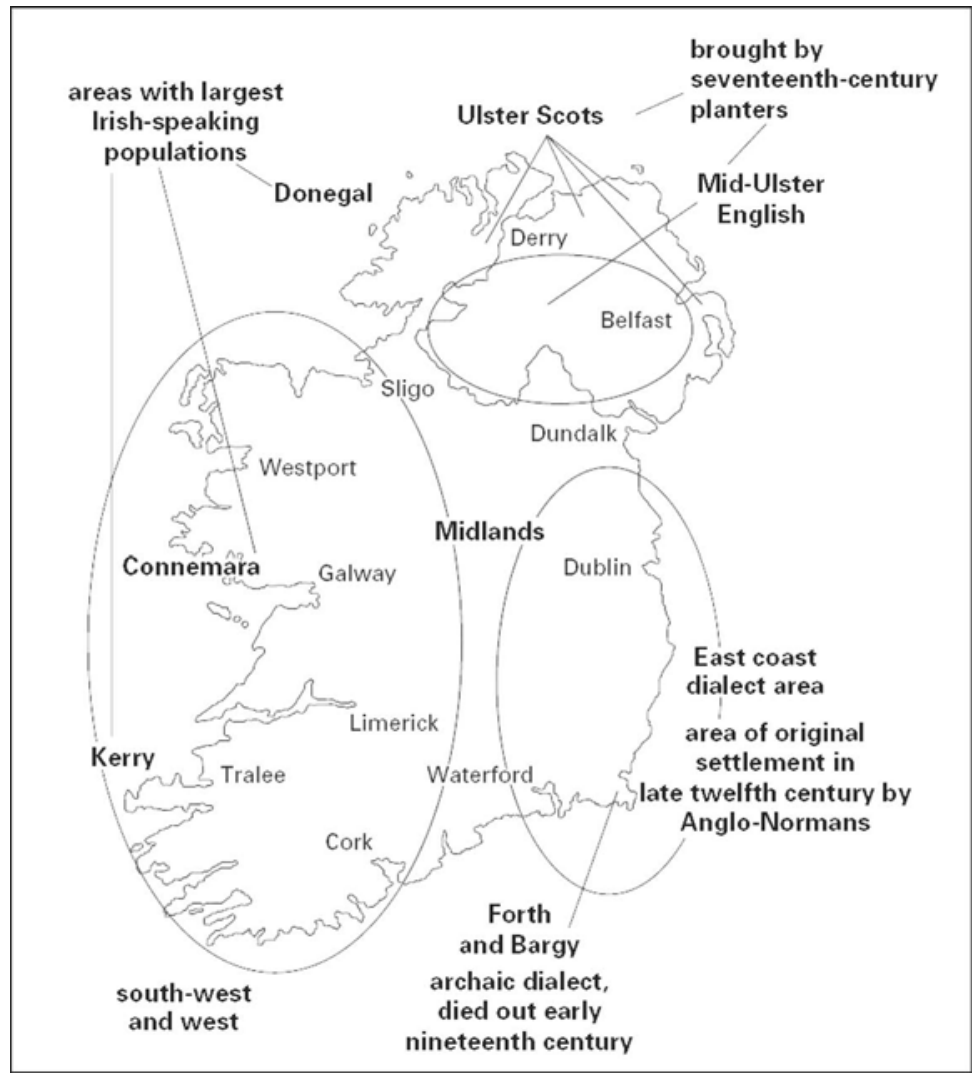

Map 3 English dialect divisions in Ireland 


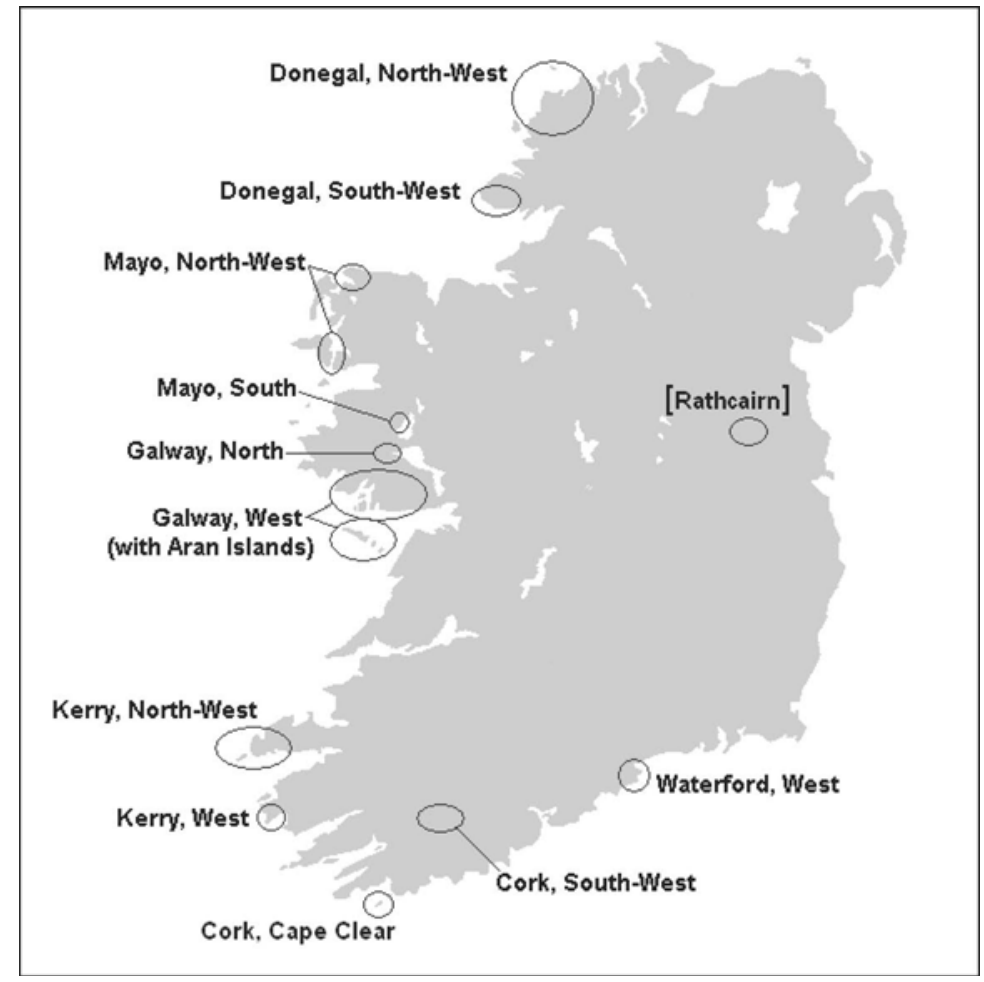

Map 4 Irish-speaking regions of Ireland 


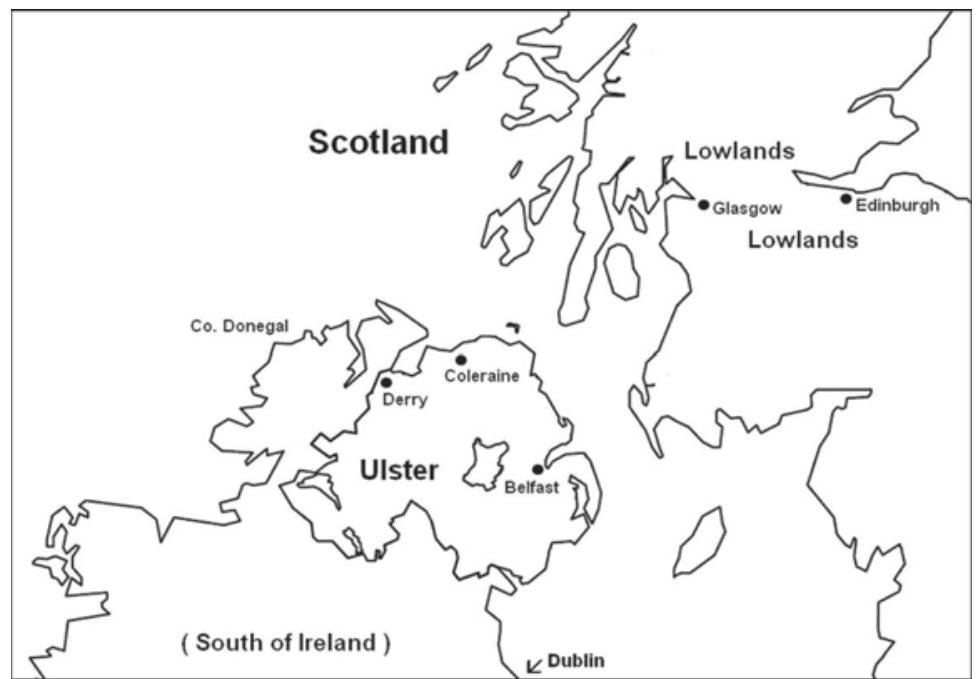

Map 5 Ulster and Scotland 